\title{
ANALISIS FAKTOR-FAKTOR KEMISKINAN MASYARAKAT PETANI DI KECAMATAN LINGGO SARI BAGANTI KABUPATEN PESISIR SELATAN Sumatera Barat-Indonesia
}

\author{
Yulhendri ${ }^{1}$, Rini Anggraini \\ Fakultas Ekonomi, Universitas Negeri Padang \\ Jl. Prof. Dr. Hamka Kampus UNP Air Tawar Barat \\ Yulhendriunp@gmail.com ${ }^{1 *}$
}

\begin{abstract}
ABSTRAK
Rendahnya tingkat pendapatan rumah tangga merupakan salah satu persoalan utama dalam perekenomian di pedesaan. Namun apa yang menyebabkan rendahnya tingkat pendapatan tersebut. Penelitian ini bertujuan untuk menganalisis faktor-faktor yang menyebabkan kemiskinan masyarakat petani di Kecamatan Linggo Sari Baganti. Populasi penelitian ini adalah petani miskin di Kecamatan Linggo Sari Baganti berjumlah 1.344 orang petani. Teknik pengambilan sampel menggunakan insidental sampling yang berjumlah 94 orang. Jenis penelitian bersifat eksploratif. Teknik analisis menggunakan analisis CFA dengan software LISREL 8.30. Hasil penelitian ini menunjukkan bahwa ada tiga faktor yang menjadi penyebab tingkat kemiskinan di Kecamatan Linggo Sari Baganti yakni pendidikan, kesempatan kerja, budaya kerja, luas lahan dan pasar.
\end{abstract}

Kata kunci: Kemiskinan Petani, penyebab kemiskinan, Ukuran Keluarga, Budaya Kerja, luas lahan.

ABSTRACT 


\section{PENDAHULUAN}

Rumah tangga miskin merupakan rumah tangga yang dikategorikan rumah tangga yang memiliki tingkat konsumsi kurang dari \$1 perhari (BPS,2015). Atau jika di rupiahkan kurang dari Rp 326.000.000,- konsumsi perbulan perkapita. Penetapan itu didasarkan pada angka garis kemiskinan (AKG) yang ditetapkan untuk mendapatkan konsumsi minimal setiap hari. Rendahnya tingkat pendapatan rumah tangga petani pada dasarnya disebabkan oleh rendahnya produktivitas petani, rendahnya kepemilikan lahan, rendahnya keterampilan yang dimiliki, rendahnya akses permodalan, dan rendahnya kemampuan mereka dalam mengadopsi teknologi pertanian. Termasuk juga keterlibatan perempuan dalam rumah tangga. (Ibiang 2016)

Indikator kemiskinan secara kuantitatif sudah banyak dikembangkan oleh para peneliti diantaranya (Wang \& Wang, 2016) menjelaskan faktor yang menyebabkan kemiskinan di China kondisinya dapat dikategorikan menjadi 3, faktor primer, faktor utama, faktor umurm dan faktor skunder. Faktor utama berkenaan dengan kurangnya fasilitas dan kondisi rumah, rendahnya layanan kesehatan, dan rendahnya tingkat pendidikan orang dewasa. Sementara itu faktor umum yakni berkenaan dengan tingkat usia sekolah, kekurangan bahan bakar, rendahnya fasilitas sanitasi, rendahnya kebersihan air bersih. Sementara itu faktor sekunder berkenaan dengan ketersediaan air, akses pada listrik dan akses pada informasi. Sejalan dengan itu (Mohanty, 2011) menelaah kondisi dan indikator kemiskinan di India bahwa indikator kemiskinan di India dapat dilihat dari aspek pendidikan, kesehatan, kondisi rumah, kondisi air, akses pada listrik, kondisi tempat memasak, kepemilikan kenderaan bermotor, telephone, televisi, komputer, radio, Ukuran kepemilikan tanah, sarana produksi pertanian. Rendahnya akses, dan kepemilikan terhadap dimensi tersebut menjadi penyebab rumah tangga berada pada kondisi miskin.

Keadaan miskin tidak dikehendaki oleh manusia/masyarakat, sebab dalam kondisi seperti itu mereka dalam keadaan serba kekurangan, tidak mampu mewujudkan berbagai kebutuhan utamanya di dalam kehidupan terutama dari segi material. Akibat ketidakmampuan material tersebut, orang miskin mengalami kesulitan untuk memenuhi kebutuhan gizinya, memperoleh pendidikan, modal kerja, dan sejumlah kebutuhan utama lainnya. Akibat lain yang ditimbulkan dari kemiskinan tersebut adalah kurangnya harga diri, moralitas yang rendah, dan kurangnya kesadaran beragama. Menurut Arraiyyah dalam Surung dan Dahlan (2012:43) pembahasan tentang kemiskinan biasanya berkisar pada dua hal utama, yaitu faktor-faktor penyebab timbulnya kemiskinan dan cara-cara yang dapat ditempuh untuk menanggulanginya dengan memanfaatkan faktor-faktor pendukung dan penghambat ke arah itu.

Beberapa hasil studi yang telah dilakukan menyimpulkan bahwa karakteristik utama dan penyebab utama kemiskinan pada wilayah miskin mencakup: 1) sumberdaya alam, 2) teknologi dan unsur pendukungnya, 3) sumberdaya manusia, dan 4) sarana dan prasarana termasuk kelembagaan (Sutanto dalam Surung dan Dahlan, 2012:43).

Besarnya peranan pertanian di Indonesia memberikan motivasi pedesaan untuk memiliki lahan pertanian yang dapat dijadikan sebagai sumber produksi, oleh karena itu mereka berupaya dengan berbagai cara untuk memenuhi lahan pertanian baik yang ada di wilayah tempat tinggalnya maupun diluar desanya. Dengan memiliki lahan pertanian tersebut, mereka akan membiayai kebutuhan hidup bagi keluarganya. Sebagian dari mereka biasanya hanya bekerja disektor pertanian karena disesuaikan dengan latar belakang pendidikan yang dimiliki.

Mengingat pentingnya faktor pertanian bagi keberadaan desa maka hal ini menjadi sebuah keniscayaan untuk memahami masyarakat desa. Masyarakat petani yang kehidupannya tergantung pada tanah sebagai sarana produksi, pada dasarnya belum melahirkan lapangan kerja yang besar variasinya. Masih banyak petani yang mengalami kesulitan dalam menjalani hidup, dalam hal ini 
adalah kesejahteraan ekonomi. Tak jarang kita dapatkan petani di desa-desa berada dalam garis kemiskinan. Hal ini disebabkan meningkatnya berbagai kebutuhan hidup, baik kebutuhan sekunder maupun primer dan juga karena terjadinya krisis ekonomi yang tak kunjung terselesaikan, inilah yang membuat para petani miskin semakin kewalahan dalam memperbaiki perekonomian keluarganya.

Tingginya tingkat pengangguran dan tingkat kemiskinan di Kecamatan ini menggugah perhatian penulis untuk menelaah dan mengkaji lebih mendalam apa yang menyebabkan rendahnya tingkat pendapatan rumah tangga di Kecamatan Linggo Sari Baganti Kabupaten Pesisir Selatan Provinsi Sumatera Barat.

\section{METODE PENELITIAN}

Penelitian ini bersifat eksploratif, dimana konsistensi penyebab rumah tangga memiliki penghasilan rendah, ditanyakan kepada responden sebagai sumber primer, dalam bentuk penilaian subyektifnya terhadap variabel yang ditanyakan. Variabel construct tidak memiliki 1 ukuran namun terdiri dari banyak ukuran. Sehingga indikator yang diajukan menjadi ukuran sebuah konstruk diuji terlebih dahulu dengan memperhatikan loading faktornya. Penelitian ini berlokasi di Kecamatan Linggo Sari Baganti pada bulan Juni-Juli 2015. Populasi dalam penelitian ini adalah seluruh masyarakat petani yang berjumlah 1.344 orang dengan sampel berjumlah 94 orang petani. Uji coba instrumen penelitian menggunakan uji validitas dan reliabilitas. Sedangkan teknik analisis data untuk melihat konsistensi indikator menjadi ukuran dianalisisi menggunakan analisis CFA (Confirmatory Factor Analysis).

\section{HASIL DAN PEMBAHASAN}

Kecamatan Linggo Sari Baganti adalah sebuah Kecamatan di Kabupaten Pesisir Selatan, yang mana namanya diambil dari gunung Linggo di Punggasan \& gunung Sari Baganti di Air Haji. Secara geografis Kecamatan Linggo Sari Baganti terletak pada $100^{0} 52$ - $101^{0} 07$ BT dan 149, $53-$ 1 Lintang Selatan, dengan luas daerah tercatat 315,41 Km atau 5,49\% dari luas Kabupaten Pesisir Selatan. Topografi daerah Kecamatan Linggo Sari Baganti datar dan berbukit-bukit sebagai perpanjangan dari Bukit Barisan, dengan tinggi dari perm ukaan laut berkisar antara 0-37 meter. Suhu udara maksimum $31^{\circ} \mathrm{C}$ dan suhu minimum $20^{\circ} \mathrm{C}$ dengan curah hujan dan jumlah hari hujan pada Oktober 2013 ini rata-rata $308 \mathrm{~m} /$ Bulan dan 17 hari/bulan.

Jika dilihat dari sudut penggunaan lahan, Kecamatan Linggo Sari Baganti, sampai saat ini masih diliputi oleh kawasan hutan. Luas kawasan hutan di Kecamatan Linggo Sari Baganti ini mencapai $27,57 \%$ dari luas daerah. Sementara lahan untuk budidaya pertanian tercatat sekitar $52,27 \%$. Sementara lahan untuk perumahan/pemukiman dan halaman sekitarnya hanya tercatat sebesar $2,29 \%$. Sisanya yaitu sebesar 1,44 persen terdiri-dari semak/alang-alang/rawa-rawa dan lainnya.

Tabel 1. Jumlah Keluarga Menurut Tingkat Kesejahteraan di Kecamatan Linggo Sari Baganti Tahun 2012-2015.

\begin{tabular}{|c|c|c|c|c|c|}
\hline Tahun & $\begin{array}{c}\text { Pra } \\
\text { Sejahtera } \\
(\boldsymbol{\%})\end{array}$ & $\begin{array}{c}\text { Sejahtera I Sejahtera II } \\
(\boldsymbol{\%})\end{array}$ & $\begin{array}{c}\text { Sejahtera II } \\
(\boldsymbol{\%})\end{array}$ & $\begin{array}{c}\text { Sejahtera III+ } \\
(\boldsymbol{\%})\end{array}$ \\
\hline $\mathbf{2 0 1 2}$ & 7 & 27 & 31 & 30 & 5 \\
\hline $\mathbf{2 0 1 3}$ & 5 & 17 & 41 & 31 & 6 \\
\hline $\mathbf{2 0 1 4}$ & 17 & 26 & 24 & 28 & 5 \\
\hline
\end{tabular}




\begin{tabular}{|l|l|l|l|l|l|}
\hline $\mathbf{2 0 1 5}$ & 10 & 15 & 38 & 31 & 6 \\
\hline
\end{tabular}

Sumber: Dinas KB Kecamatan Linggo Sari Baganti, tahun 2012- 2015

Dari data Tabel 1 di atas menunjukkan jumlah kepala keluarga menurut tingkat kesejahteraan di Kecamatan Linggo Sari Baganti dari Tahun 2012-2015 berfluktuasi. Banyaknya keluarga pra sejahtera dan sejahtera I pada Tahun 2012 tercatat masing-masing yaitu sebesar 7\% dan $27 \%$, sedangkan jumlah keluarga sejahtera II sebesar $31 \%$, sejahtera III sebesar $30 \%$ dan sejahtera III+ sebesar 5\%. Jumlah keluarga pra sejahtera dan sejahtera I pada Tahun 2013 tercatat masing-masing yaitu sebesar 5\% dan 17\%, sedangkan jumlah keluarga sejahtera II sebesar 41\%, sejahtera III sebesar $31 \%$ dan sejahtera III+ sebesar 6\%. Jumlah keluarga pra sejahtera dan sejahtera I pada Tahun 2014 tercatat masing-masing yaitu sebesar 6\% dan 16\%, sedangkan jumlah keluarga sejahtera II sebesar 40\%, sejahtera III sebesar 33\% dan sejahtera III+ sebesar 5\%. Jumlah keluarga pra sejahtera dan sejahtera I pada Tahun 2015 tercatat masing-masing yaitu sebesar 10\% dan $15 \%$., sedangkan jumlah keluarga sejahtera II sebesar 38\%, sejahtera III sebesar $31 \%$ dan sejahtera III+ sebesar 6\%.

Tabel 2. Jumlah Kepala Keluarga dan Kepala Keluarga Miskin di Kecamatan Linggo Sari Baganti Tahun 2015.

\begin{tabular}{|l|c|c|c|c|c|c|}
\hline Nagari & $\begin{array}{c}\text { Kepala } \\
\text { Keluarga }\end{array}$ & $\begin{array}{c}\text { Kepala } \\
\text { Keluarga } \\
\text { Miskin }\end{array}$ & $\begin{array}{c}\text { \% } \\
\text { KK } \\
\text { Miskin }\end{array}$ & Bekerja & $\begin{array}{c}\text { Tidak } \\
\text { Bekerja }\end{array}$ & $\begin{array}{c}\text { \% KK } \\
\text { Pengangguran }\end{array}$ \\
\hline Air Haji & 773 & 46 & 5,95 & 722 & 51 & 7,06 \\
\hline Pasar Lama M.AH & 902 & 144 & 15,96 & 695 & 207 & 29,78 \\
\hline Muara Gadang & 884 & 158 & 17,87 & 710 & 174 & 24,51 \\
\hline Air Haji Barat & 731 & 42 & 5,75 & 649 & 82 & 12,63 \\
\hline Pasar Bukit AH & 671 & 45 & 6,71 & 633 & 38 & 6,00 \\
\hline Sungai Sirah & 607 & 43 & 7,08 & 586 & 21 & 3,58 \\
\hline Rantau Sumalenang & 998 & 168 & 16,83 & 817 & 181 & 22,15 \\
\hline Air Haji Tengah & 778 & 56 & 7,20 & 694 & 84 & 12,10 \\
\hline Air Haji Tenggara & 936 & 43 & 4,59 & 822 & 114 & 13,87 \\
\hline Punggasan & 808 & 148 & 18,32 & 654 & 154 & 23,55 \\
\hline Muara Kandis P. & 661 & 34 & 5,14 & 593 & 68 & 11,47 \\
\hline Padang X1 P. & 864 & 45 & 5,21 & 808 & 56 & 6,93 \\
\hline Punggasan Timur & 1.113 & 146 & 13,12 & 898 & 215 & 23,94 \\
\hline Punggasan Utara & 1.168 & 148 & 12,67 & 959 & 209 & 21,79 \\
\hline Lagan Hilir P. & 679 & 47 & 6,92 & 619 & 60 & 9,69 \\
\hline Lagan Mudik P. & 638 & 31 & 4,86 & 617 & 21 & 3,40 \\
\hline & & & & & 15,12 \\
\hline Jumlah & $\mathbf{1 3 . 2 1 1}$ & $\mathbf{1 . 3 4 4}$ & $\mathbf{1 0 , 1 7}$ & $\mathbf{1 1 . 4 7 6}$ & $\mathbf{1 . 7 3 5}$ & $\mathbf{1 5}$ \\
\hline
\end{tabular}

Sumber : Kantor Camat Linggo Sari Baganti 2016

Dari data Tabel 2 di atas menunjukkan bahwa jumlah kepala keluarga yang ada di Kecamatan Linggo Sari Baganti yang tersebar dienam belas Nagari yaitu berjumlah 13.211 kepala keluarga dan terdapat 1.344 kepala keluarga miskin. Jumlah kepala keluarga yang dikategorikan miskin $10,17 \%$. Sementara itu tingkat pengangguran justru lebih tinggi dari tingkat kemiskinan

Jumlah kepala keluarga menurut status pekerjaan masing-masing Nagari bebeda-beda. Jumlah kepala keluarga yang paling banyak memiliki pekerjaan terdapat di Punggasan Utara yaitu 
sebesar 9\% atau sebanyak 959 kepala keluarga dengan total keseluruhan kepala keluarga yang bekerja di Kecamatan Linggo Sari Baganti yaitu sebesar 87\% atau sebanyak 11.476 kepala keluarga. Kepala keluarga yang paling banyak tidak bekerja terdapat di Nagari Punggasan Timur, Punggasan Utara dan Pasar Lama Muara Air Haji yaitu sebesar 12\% yang masing-masing sebanyak 215, 209 dan 207 kepala keluarga dengan total keseluruhan yang tidak bekerja yaitu sebesar 13\% atau sebanyak 1.735 kepala keluarga. sedangkan yang paling sedikit kepala keluarga yang tidak bekerja terdapat di Nagari Sungai Sirah Air Haji dan Lagan Mudik Punggasan yaitu sebesar $1 \%$. Status pekerjaan sangat mempengaruhi terhadap kemiskinan apabila suatu rumah tangga mempunyai pekerjaan dan penghasilan yang tetap, maka kebutuhan ekonomi akan terpenuhi dan kesejahteraan masyarakat akan tercapai, sehingga akan jauh dari kemiskinan dan sebaliknya.

Penelitian ini merupakan penelitian konfirmatif, dimana rendahnya pendapatan rumah tangga itu atau tingkat kemiskinan menurut masyarakat merupakan faktor yang dialami setiap hari dari waktu kewaktu. Konsistensi jawaban oleh responden dibuktikan oleh nilai faktor loading yang didapatkan pada setiap dimensi yang membentuk faktor pembentuk kemiskinan di Kecamatan Linggo Sari Baganti. Berikut ini dimensi dan ukuran yang diajukan dan nilai faktor loading dan nilai t-value untuk masing-masing item.

Tabel 3 : Dimensi, Indikator Item dan Nilai Faktor Loading Variabel

\begin{tabular}{|c|c|c|c|c|}
\hline Dimensi & Indikator & Item & $\begin{array}{l}\text { Faktor } \\
\text { Loading }\end{array}$ & Keterangan \\
\hline \multirow[t]{4}{*}{ Modal } & Modal kerja & $\begin{array}{l}\text { Keterbatasan } \\
\text { modal kerja }\end{array}$ & 0,42 & TMK \\
\hline & Peralatan & Keterbatasan peralatan & 0,64 & MMK \\
\hline & Bibit & Keterbatasan bibit & 0,44 & TMK \\
\hline & Pupuk & $\begin{array}{l}\text { Keterbatasan Pengadaan } \\
\text { pupuk }\end{array}$ & 0,42 & TMK \\
\hline \multirow[t]{4}{*}{ Teknologi } & Mesin & $\begin{array}{l}\text { Tidak bisa menggunakan } \\
\text { mesin bajak }\end{array}$ & 0,63 & Valid \\
\hline & $\begin{array}{l}\text { Pengetahuan } \\
\text { bibit }\end{array}$ & $\begin{array}{l}\text { Pengetahuan rendah tentang } \\
\text { bibit }\end{array}$ & 0,49 & TMK \\
\hline & $\begin{array}{l}\text { Pengetahuan } \\
\text { pupuk }\end{array}$ & $\begin{array}{ll}\text { Pengetahuan } & \text { rendah } \\
\text { terhadap pupuk }\end{array}$ & 0,47 & TMK \\
\hline & $\begin{array}{l}\text { Pengetahuan } \\
\text { hama }\end{array}$ & \begin{tabular}{lr}
\multicolumn{2}{l}{ Pengetahuan rendah } \\
terhadap cara membasmi \\
hama
\end{tabular} & 0,34 & TMK \\
\hline \multirow[t]{3}{*}{$\begin{array}{l}\text { Akses } \\
\text { kredit }\end{array}$} & $\begin{array}{l}\text { Akses terhadap } \\
\text { perbankan }\end{array}$ & $\begin{array}{l}\text { Kesulitan dalam dalam } \\
\text { mengakses kredit perbankan }\end{array}$ & 0,59 & MMK \\
\hline & $\begin{array}{l}\text { Akses terhadap } \\
\text { koperasi }\end{array}$ & $\begin{array}{l}\text { Kesulitan dalam dalam } \\
\text { mengakses kredit Koperasi }\end{array}$ & 0,43 & TMK \\
\hline & $\begin{array}{l}\text { Sulit akses pada } \\
\text { kredit program }\end{array}$ & $\begin{array}{l}\text { Kesulitan dalam dalam } \\
\text { mengakses kredit Tani }\end{array}$ & 0,27 & TMK \\
\hline \multirow{3}{*}{$\begin{array}{l}\text { Pendapata } \\
\text { n }\end{array}$} & Kecukupan & Pendapatan rendah & 0,59 & MMK \\
\hline & Jenis Pekerjaan & Buruh Tani & 0,43 & TMK \\
\hline & Hasil Pertanian & Hasil produksi rendah & 0,27 & TMK \\
\hline \multirow[t]{3}{*}{$\begin{array}{l}\text { Jumlah } \\
\text { tanggunga } \\
\text { n keluarga }\end{array}$} & $\begin{array}{l}\text { Anggota } \\
\text { keluarga }\end{array}$ & $\begin{array}{l}\text { Produksi pertanian tidak } \\
\text { seimbang dengan jumlah } \\
\text { keluarga }\end{array}$ & 0,26 & TMK \\
\hline & Keterpenuhan & $\begin{array}{l}\text { Ketidakcukupan memenuhi } \\
\text { kebutuhan keluarga }\end{array}$ & 1,16 & MMK \\
\hline & Bekerja Keras & Bekerja keras memehuhi & 0,23 & TMK \\
\hline
\end{tabular}




\begin{tabular}{|l|l|l|l|l|}
\hline & & kebutuhan keluarga & & \\
\hline $\begin{array}{l}\text { Usaha } \\
\text { Sampingan }\end{array}$ & $\begin{array}{l}\text { Usaha } \\
\text { sampingan }\end{array}$ & Memiliki usaha sampingan & 0,38 & TMK \\
\hline
\end{tabular}

\begin{tabular}{|c|c|c|c|c|}
\hline Dimensi & Indikator & Item & $\begin{array}{l}\text { Loading } \\
\text { Faktor }\end{array}$ & Keterangan \\
\hline \multirow[t]{4}{*}{ Pendidikan } & $\begin{array}{l}\text { Pendidikan dan } \\
\text { Upah }\end{array}$ & $\begin{array}{l}\text { Upah yang rendah karena } \\
\text { pendidikan yang rendah }\end{array}$ & 0,03 & TMK \\
\hline & Peralatan & Keterbatasan peralatan & 0,46 & TMK \\
\hline & $\begin{array}{l}\text { Pendidikan dan } \\
\text { pekerjaan }\end{array}$ & $\begin{array}{lr}\text { Sulit mendapatkan } \\
\text { pekerjaan } & \text { karena } \\
\text { Pendidikan yang rendah }\end{array}$ & 0,48 & TMK \\
\hline & $\begin{array}{l}\text { Pendidikan dan } \\
\text { pekerjaan } \\
\text { sampingan }\end{array}$ & $\begin{array}{l}\text { Karena pendidikan rendah } \\
\text { tak ada pekerjaan } \\
\text { sampingan }\end{array}$ & 0,44 & TMK \\
\hline \multirow[t]{4}{*}{$\begin{array}{l}\text { Kesempata } \\
\text { n kerja }\end{array}$} & $\begin{array}{l}\text { Pekerjaan } \\
\text { musiman }\end{array}$ & $\begin{array}{l}\text { Memiliki pekerjaan } \\
\text { musiman }\end{array}$ & 0,49 & TMK \\
\hline & $\begin{array}{l}\text { Kubutuhan } \\
\text { kerja }\end{array}$ & $\begin{array}{l}\text { Tidak memiliki pekerjaan } \\
\text { karena permintaan rendah }\end{array}$ & 0,54 & MMK \\
\hline & Waktu kerja & Waktu kerja rendah & 0,54 & MMK \\
\hline & Buruh tani & $\begin{array}{l}\text { Pekerjaan yang dijalani } \\
\text { menjadi buruh tani }\end{array}$ & 0,54 & MMK \\
\hline \multirow[t]{3}{*}{$\begin{array}{l}\text { Budaya } \\
\text { kerja }\end{array}$} & Kerja Sendiri & $\begin{array}{l}\text { Melakukan sendiri semua } \\
\text { pekerjaan }\end{array}$ & 0,49 & TMK \\
\hline & $\begin{array}{l}\text { Pekerjaan } \\
\text { serentak }\end{array}$ & $\begin{array}{lll}\begin{array}{l}\text { Bertanam } \\
\text { serentak }\end{array} & \text { padi } & \text { secara } \\
\end{array}$ & 0,54 & MMK \\
\hline & Gotong royong & $\begin{array}{l}\text { Melakukan pekerjaan } \\
\text { dengan gotong royong }\end{array}$ & 0,64 & MMK \\
\hline \multirow[t]{4}{*}{ Luas lahan } & Produktivitas & Produktivitas lahan rendah & 0,55 & MMK \\
\hline & Luas lahan & $\begin{array}{l}\text { Luas lahan rendah/sempit, } \\
\text { kurang dari } 0,5 \text { ha }\end{array}$ & 0,65 & MMK \\
\hline & $\begin{array}{ll}\begin{array}{l}\text { Luas } \\
\text { sedang }\end{array} & \text { lahan } \\
\end{array}$ & Luas lahan lebih dari 0,5 ha & 0,57 & MMK \\
\hline & $\begin{array}{ll}\text { Luas } & \text { lahan } \\
\text { sewa } & \\
\end{array}$ & $\begin{array}{l}\text { Luas lahan sewa kurang } \\
\text { dari } 0,5 \text { ha }\end{array}$ & 0,36 & TMK \\
\hline \multirow[t]{2}{*}{ Pasar } & Harga & Harga yang dijual rendah & 0,56 & MMK \\
\hline & Akses ke Pasar & Akses ke Pasar Renah & 0,57 & MMK \\
\hline
\end{tabular}

Sumber, Data diolah, tahun , 2016

Keterangan: $\mathrm{TMK}=$ Tidak memenuhi kriteria, dan MMK = memenuhi kriteria. 


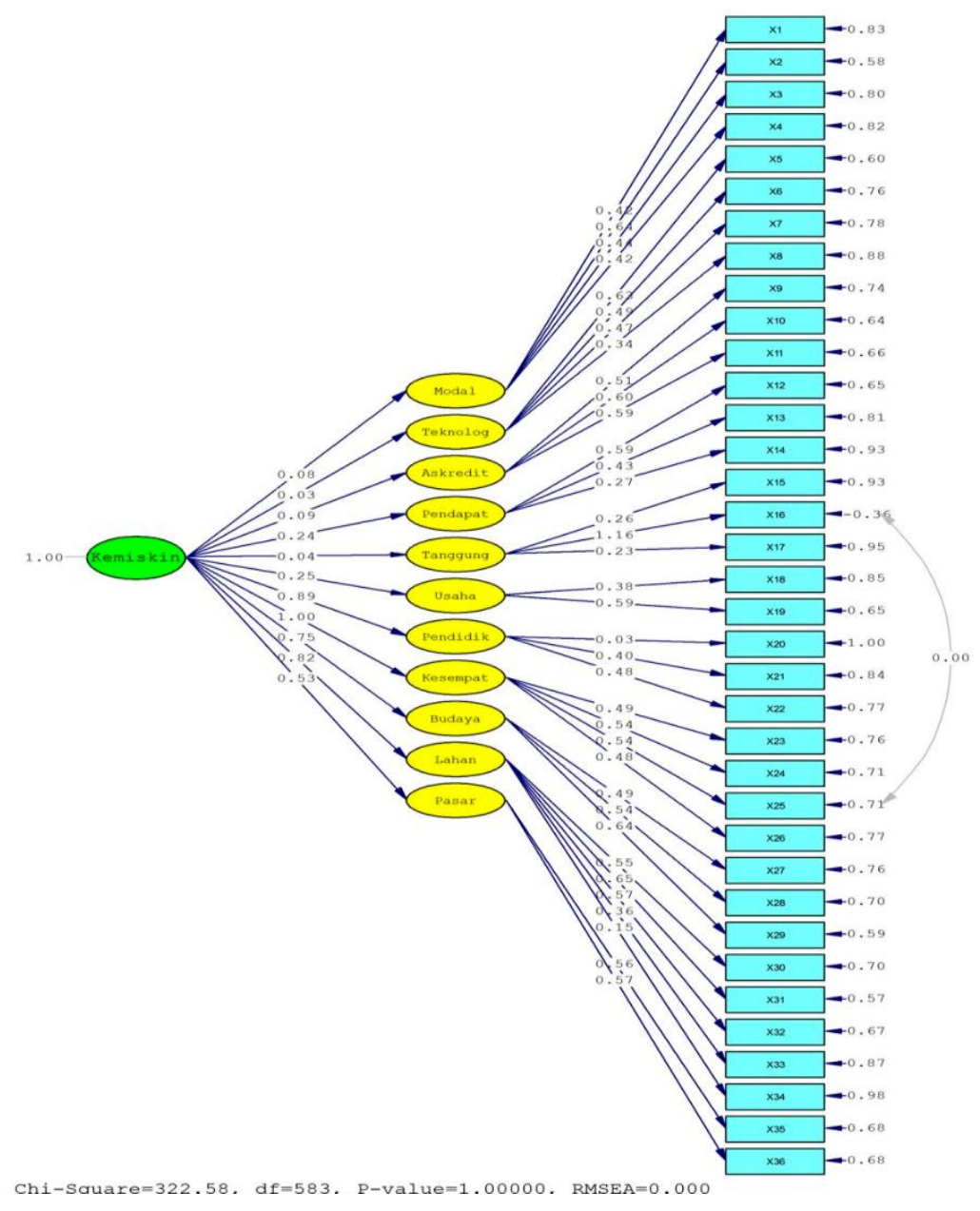

Gambar 1: 2ndCFA, Model Awal Penelitian

Setelah dilakukan pengujian dengan melihat faktor loading atau nilai t-value dari indikator faktor pembentuk ukuran kemiskinan tersebut. Maka seluruh indikator yang tidak memenuhi syarat atau kriteria yang ditetapkan nilai faktor loading lebih tinggi dari 0,50 atau nilai t-value kecil dari 1,96. Maka indikator tersebut dibuang dari model. Sehingga diperolah indikator-indikator yang betul-betul memenuhi syarat yang ditentukan. Sehingga dapat dikatakan bahwa ukuran dari penyebab tingkat kemiskinan dapat menjadi konsisten dan valid. 
Dari hasil pengolahan data, deskripsi masing-masing variabel yang dapat dilihat pada tabel 5 berikut:

Tabel 5. Nilai Faktor Loading dan T-value

\begin{tabular}{|l|l|c|c|l|}
\hline No & \multicolumn{1}{|c|}{ Indikator } & $\begin{array}{c}\text { Faktor } \\
\text { Loading }\end{array}$ & $\begin{array}{c}\text { T- } \\
\text { value }\end{array}$ & \multicolumn{1}{|c|}{ Keterangan } \\
\hline 1. & Modal & 0.08 & 0,53 & Tidak memenuhi kriteria \\
\hline 2. & Teknologi & 0,03 & 0,20 & Tidak memenuhi kriteria \\
\hline 3. & Akses Kredit & 0,09 & 0,59 & Tidak memenuhi kriteria \\
\hline 4. & Pendapatan & 0,24 & 1,30 & Tidak memenuhi kriteria \\
\hline 5. & Jumlah Tanggungan Keluarga & 0,04 & 0,34 & Tidak memenuhi kriteria \\
\hline 6. & Alternatif Usaha & 0,25 & 1,18 & Tidak memenuhi kriteria \\
\hline 7. & Pendidikan & 0,89 & 0,84 & Memenuhi kriteria \\
\hline 8. & Kesempatan Kerja & 1.00 & 0,08 & Memenuhi Kriteria \\
\hline 9. & Budaya Kerja & 0,75 & 2,88 & Memenuhi Kriteria \\
\hline 10. & Luas Lahan & 0,82 & 2,75 & Memenuhi Kriteria \\
\hline 11. & Pasar & 0,53 & 2,47 & Memenuhi kriteria \\
\hline
\end{tabular}

Sumber: Pengolahan Data Prime, 2016

Dimesi yang memenuhi syarat menjadi ukuran kemiskinan yakni Pendidikan, Kesempatan kerja, Budaya kerja, luas lahan dan akses pada pasar. Tabel 5 diatas, menerangkan bahwa nilai faktor loading dan t value, CFA yang dapat diterima, yaitu yang mempunyai kecocokan data model, validitas dan reabilitas yang baik. Salah satu caranya ialah dengan model trimming, dimana variabel-variabel teramati / indikator yang mempunyai standardized loading faktor tidak signifikan (nilai t-value $\leq$ 1,96 dan yang signifikan tetapi nilai standardized loading faktor $\leq$ 0,70 (Rigdon dan Ferguson, 1997; Doll, Xia, dan Torkzadeh, 1994) atau $\leq$ 0,50 (Igbaria et.al.,1997) dalam Wijanto (2008:69) maka dihilangkan dari model.

Variabel modal, teknologi, akses kredit, pendapatan, jumlah tanggungan keluarga, dan alternatif usaha dihilangkan dari modetidak signifikan mempengaruhi kemiskinan petani di Kecamatan Linggo Sari Baganti. Sedangkan variabel pendidikan, kesempatan kerja, budaya kerja, luas lahan dan pasar signifikan mempengaruhi kemiskinan petani di Kecamatan Linggo Sari Baganti. Untuk lebih jelas dapat dilihat pada gambar 2 dan gambar 3.

\section{Uji Kecocokkan}

\section{Ukuran kecocokkan absolute}

Ukuran kecocokkan absolut mengandung ukuran-ukuran yang mewakili sudut pandang overall fit. Ukuran ini dapat di lihat pada tabel dibawah ini : 
Tabel 6. Hasil Uji Kecocokkan Absolut

\begin{tabular}{|l|l|l|l|}
\hline Ukuran Goodness of Fit & \multicolumn{1}{|c|}{$\begin{array}{c}\text { Kriteria } \\
\text { Kecocokkan }\end{array}$} & $\begin{array}{c}\text { Hasil } \\
\text { estimasi }\end{array}$ & Keterangan \\
\hline Chi-Square & Nilai yang kecil & 140,40 & Poor fit \\
P $\leq 0,05$ & & \\
\hline NCP & Nilai yang besar & 84,15 & Good Fit \\
Interval & Interval yang sempit & $(54,32 ;$ & \\
& & $121,61)$ & \\
\hline RMSEA & RMSEA $\leq 0,08$ & 0,15 & Poor Fit \\
P (close fit) & p $\geq 0,05$ & $(0,12 ;$ & \\
& & $0,18)$ & \\
\hline ECVI & Nilai yang kecil dan & M= & Good Fit \\
& dekat dengan ECVI & 1,89 & \\
& saturated & $\mathrm{S}=1,42$ & \\
& & $\mathrm{I}=6,43$ & \\
\hline RMR & RMR $\leq 0,05$ & 0,093 & Poor Fit \\
\hline GFI & GFI $\geq 0,90$ & 0,80 & Marjinal Fit \\
\hline
\end{tabular}

Sumber : Output LISREL hasil olahan peneliti 2016

Ukuran yang paling dominan yang membentuk faktor kemisiknan rumah tangga di pedesaan yakni:

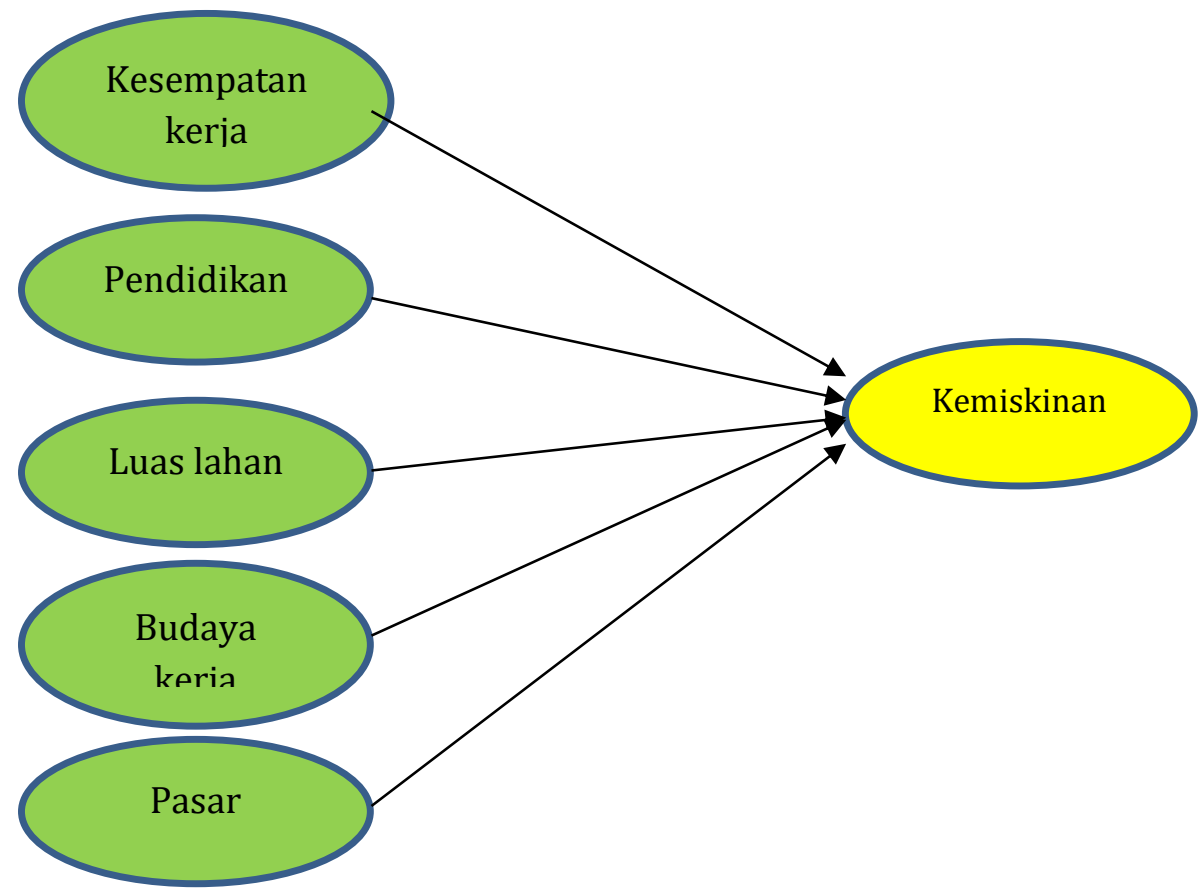

Gambar: Faktor Dominan Penyebab Kemiskinan 
Penelitian ini sejalan dengan teori umum dalam pembangunan bahwa kecakapan dan kepintaran Sumberdaya manusia menjadi faktor penentu tinggi rendahnya tingkat pendapatan seseorang (Becker, 1994).

Rendahnya kegiatan ekonomi di Pedesaan menyebabkan kesempatan kerja juga terbatas di pedesaan. Pada umumnya bidang usaha dan pekerjaan yang ada di Desa hanya dua sektor yakni pertanian, perdagangan dan transportasi/pengangkutan.

Faktor Kesempatan kerja, Kesempatan kerja di pedesaan amat terbatas: 1) Pekerjaan ada karena ada kaitannya dengan pekerjaan musiman, jika musim habis maka pekerjaan habis, misalnya musim tanam dan musim panen raya. 2)

Faktor Pendidikan, Kemiskinan di daerah pedesaan disebabkan karena Faktor Pendidikan: 1) Keterbatasan petani alam menggunakan peralatan, 2). Petani kesulitan mendapatkan pekerjaan sampingan karena tidak memiliki keterampilan yang memadai, 3) kesulitan dalam mendapatkan pekerjaan. 4) Waktu kerja relatif rendah, 5) sebagian besar petani menjadi buruh tani. Ini sejalan dengan penelitian yang dilakukan oleh

Faktor lahan, Petani dalam kehidupan perekonomian dihadapkan dengan masalah : 1) Rendahnya produktivitas lahan, 3) bertani dilahan yang sempit.

Faktor budaya kerja, petani dalam kebiasaan kerja diantaranya: 1) Melakukan sendiri semua pekerjaan pertanian tanpa melibatkan pekerja lain, selain pekerjaan tanam dan panen padi. 2). Bertanam padi, 3) melakukan aktivitas pertanian dengan pola gotong royong.

Faktor akses dengan pasar. Kemiskinan juga dipengaruhi oleh faktor akses dengan pasar dimana petani memiliki kelemahan dalam menjual hasil panen dengan harga atau nilai tukar petani yang lebih baik, dan akses mereka ke penjualan hasil pertanian juga tidak terlalu luas.

Beberapa riset telah banyak menjelaskan penyebab tingkat kemiskinan pada suatu negara atau dalam konteks masyarakat di Indonesia seperti yang dilakukan oleh Kartasasmita dalam Setiadi dan Kolip (2011:803) hal ini di sebut accidental poverty yaitu kemiskinan karena dampak dari kebijaksanaan tertentu yang meyebabkan menurunnya tingkat kesejahteraan masyarakat. Masalah-masalah kemiskinan tersebut di atas menurut Nurkse dalam Setiadi dan Kolip (2011:804) sebagai lingkaran setan kemiskinan yang meliputi enam unsur, yaitu : (1) Keterbelakangan, (2) Kekurangan modal, (3) Investasi rendah, (4) Tabungan rendah, (5) Pendapatan rendah, dan (6) Produksi rendah.

Negara terbelakang umumnya terjerat ke dalam apa yang disebut lingkaran setan kemiskinan. Menurut Nurkse dalam Jhingan (2012:33) menjelaskan: lingkaran setan mengandung arti deretan melingkar kekuatan-kekuatan yang satu sama lain beraksi dan bereaksi sedemikian rupa sehingga menempatkan suatu negara miskin tetap berada dalam keadaan melarat. Si miskin, misalnya, selalu kurang makan, karena kurang makan kesehatannya menjadi buruk; karena fisiknya lemah kapasitas kerjanya rendah; karena kapasitas kerjanya rendah penghasilannya pun rendah, dan itu berarti ia miskin, akhirnya ia tidak akan mempunyai cukup makan; dan seterusnya. 


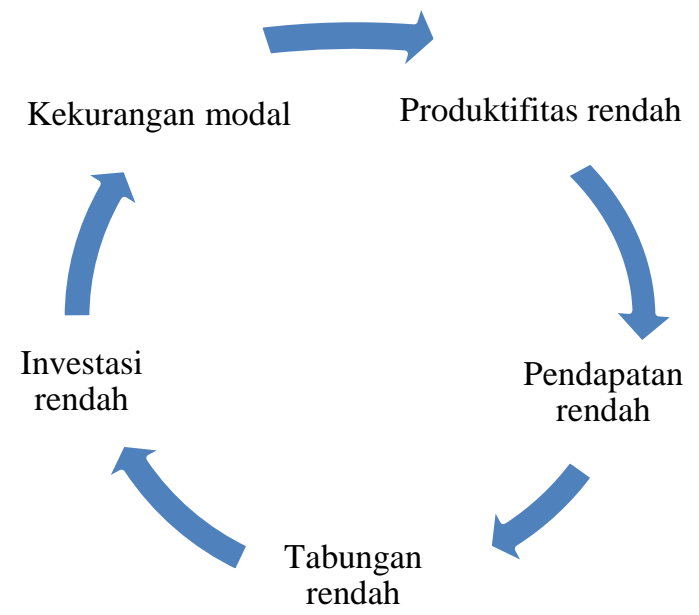

Gambar 1. Lingkaran Setan Kemiskinan (The Vicious Circle of Proverty)
Sumber : Jhingan (2012:34)

Lingkaran setan pada gambar $1 \mathrm{di}$ atas menjelaskan bahwa produktivitas rendah tercemin di dalam pendapatan nyata yang rendah. Pendapatan nyata rendah berarti tingkat tabungan juga rendah. Tingkat tabungan yang rendah menyebabkan tingkat investasi rendah dan modal kurang. Kekurangan modal pada gilirannya bermuara pada produktivitasnya yang rendah dan seterusnya.

\section{PENUTUP}

Ternyata ditemukan bahwa kemiskinan di sektor pertanian lebih konsisten faktorfaktor Pendidikan, kesempatan kerja, budaya kerja, luas lahan dan akses pada pasar yang menjadi pembentuk rumah tangga miskin. Tingkat pendidikan yang rendah, membuat rumah tangga tidak memiliki pengetahuan yang cukup untuk menjalankan usaha pertanian lebih tinggi lagi dalam hal penggunaan bibit yang baik, pupuk, pembasmian hama dan penggunaan teknologi pertanian. Tingkat pendidikan yang rendah juga membuat kesempatan kerja petani pada bidang lain menjadi rendah. Pada saat mereka sudah selesai mengerjakan lahan, sudah selesai bertanam, memumpuk, menyiang dan panen Petani sebenarnya memiliki waktu luang yang cukup banyak untuk bekerja pada bidang lain. Namun karena tingkat pengetahuan, dan keterampilan pada bidang lain rendah. Akhirnya waktu senggang tidak banyak digunakan untuk produktif tetapi justru konsumtif. Maka inilah yang menjadi salah satu titik poin penting keluarnya mereka pada status rumah tangga miskin. Budaya kerja yang rendah dimana sikap bekerja gotong royong yang rendah, lebih banyak bekerja sendiri, dan terkadang tidak serentak dalam periode tanam. Petani yang berhasil adalah petani yang sikap berkelompoknya yang tinggi, gotong royong dan mampu bersinergi dalam menentukan waktu tanam. Termasuk juga luas lahan, luas lahan yang sempit membuat jumlah produksi pertanian akan tidak mampu mencukupi kebutuhan keluarga. Jika dihitung lebih teliti hasil produksi panen jika dibandingkan dengan biaya produksi justru lebih rendah sehingga sebenarnya mereka berada pada 
aktivitas ekonomi yang tidak menguntungkan. Pasar mempengaruhi terhadap harga bahwa petani mengalami kesulitan untuk menjual hasil produksi dengan harga yang tinggi yang dekat dari pasar serta sulitnya menjual hasil produksi dengan harga yang murah dan jauh dari pasar.

\section{Saran}

Saran, memperbaiki akses pendidikan di pedesaan menjadi perhatian publik yang harus diperbaiki, mendorong alokasi anggaran negara untuk pedesaan akan mendorong permintaan pekerjaan di pedesaan sehingga petani memiliki kesempatan kerja pada saat tidak musim tanam dan panen. Lahan-lahan produktif yang subur, dan datar pada umumnya telah dimiliki oleh pemilik modal besar sehingga diperlukan pola pengelolaan pertanian yang mengedepankan peruntukan bagi pertanian rakyat. Dan pola manajemen komunal sebaiknya diganti dengan pola manajemen perusahaan dengan kepemilikan petani akan membantuk petani dalam meningkatkan produktivitas dan akses pasar pada usaha pertanian mereka.

\section{DAFTAR PUSTAKA}

Garry S.Becker(The University o Chicago Press, 1994. No Title,

Ibiang, E.I., 2016. RURAL POVERTY AND FAO'S PLAN OF ACTION Published by :

Canadian Mennonite University Stable URL : http://www.jstor.org/stable/23607359. , 29(1), pp.11-13.

Mohanty, S.K., 2011. Multidimensional Poverty and Child Survival in India. , 6(10).

Wang, Y. \& Wang, B., 2016. Multidimensional poverty measure and analysis : a case study from Hechi City , China. SpringerPlus. Available at: "http://dx.doi.org/10.1186/s40064-016-21927.

Amar Syamsul. 1999. Analisis Ekonomi tentang Kemiskinan dan Implikasi Kebijaksanaan Pengentasannya di Pedesaan Propinsi Sumatera Barat, Pasca Sarjana Universitas Airlangga, Surabaya.

Arrochmah Hesti. 2012. Kajian penduduk petani miskin desa candra kencana Kecamatan Tulang Bawang Tengah Kabupaten tulang bawang barat tahun. Melalui http://docs.google.com p.unila.ac.id/ojs/data/journals.

Arikunto, Suharsimi. 2006. Prosedur Penelitian Suatu Pendekatan Praktik. Jakarta: Rineka Cipta. 
Arraiyyah, H. 2007. Meneropong Fenomena Kemiskinan (Telaah Perspektif Al-Qur'an). Yogyakarta: Pustaka Pelajar.

Badan Pusat Statistik. 2014. Kecamatan Linggo Sari Baganti Dalam Angka 2014.

Benjamin Chijioke Asogwa, Victoria Ada Okwoche, dan Joseph Chinedu Umeh. 2012. Analysing the Determinants of Poverty Severity among Rural Farmers in Nigeria: A Censored Regression Model Approach American International Journal of Contemporary Research. Vol.2 No.5; May 2012.

Banowati, Eva dan Sriyanto. 2013. Geografi Pertanian. Yogyakarta: Ombak.

Chriswardani Suryawati, 2005. Memahami Kemiskinan Secara Multidimensional. Jurnal Manajemen Pelayanan Kesehatan Vol.08/No.03/Septembe/2005.Hal 121-129.

Chambers, Robert (1997). Whose really counts? Putting the first last. London: Intermediate Technology Publication.

Ginting, Jamilah. 2004. Analisis Faktor Penyebab Pendapatan Petani Miskin di Kecamatan Deli Tua Kabupaten Deli Serdang, Pasca Sarjana Universitas Sumatera Utara.

Hanafie, Rita. 2010. Pengantar Ekonomi Pertanian. Yogyakarta: C.V Andi Offset.

Idris. 2010. Aplikasi Model Analisis Data Kuantitatif Dengan Program SPSS Edisi Revisi III. Padang : Fakultas Ekonomi Universitas Negeri Padang.

Istijanto, MM. 2005. Aplikasi Praktis Riset Pemasaran. Jakarta: PT Gramedia Pustaka.

Ibnussalam, 2002. Analisis Faktor-faktor Penyebab Kemiskinan masyarakat Desa (Suatu study pada Desa Bulucina, Tarutungsihoda-hoda dan Desa Gonting Jae Kecamatan Burumun Tengah Kabupaten Tapanuli Selatan), Pasca Sarjana USU Medan.

Jhingan, M.L. 2012. Ekonomi Pembangunan dan Perencanaan. Jakarta : PT. Raja Grafindo Persada.

M. Thamrin, Noor 2005. "Faktor-Faktor yang berpengaruh terhadap Kemiskinan di Kabupaten Kotawaringin Kalimantan Tengah”. Jurnal Aplikasi Manajemen, Vol.3, No.2, Agustus 2005.

Setiadi, M. Elly dan Kolip Usman. 2011. Pengantar Sosiologi. Pemahaman Fakta dan Gejala Permasalahan Sosial : Teori, Aplikasi, dan Pemecahannya. Kencana Prenadamedia Group.

Slamet, Yulius. 2007. Kemiskinan Petani Pedesaan: Analisis Mengenai Sebab-sebab Kemiskinan, Seminar Nasional Laboratorium Sosiologi: Penerbit UNS.

Sugiyono. 2009. Metode Penelitian Pendidikan. Bandung: Alfabeta.

Soekartawi. 1995. Analisis Usahatani. 1995. Jakarta: Universitas Indonesia (UI-Press). 
Soekartawi. 1996. Pembangunan Pertanian Upaya Pengentasan Kemiskinan. Jakarta: Penerbit Universitas Indonesia (UI-Press).

Scott, J.C. 1997. The Moral Economy of The Peasant. Rebellion and Subsistence in Southeast Asia. Yale University Press. London.

Sayogyo. 1973. Golongan miskin dan Partisipasinya dalam Pembangunan Desa, Prisma No. 3 Tahun 1977, PL3ES, Jakarta.

Supadi dan Nurmanaf Rozany, Achmad. 2004. Pendapatan dan Pengeluaran Rumah Tangga Pedesaan dan Kaitannya dengan Tingkat Kemiskinan. Pusat Analisis Sosial Ekonomi dan Kebijakan Pertanian, Bogor.

Surung M. Yacob dan Dahlan. 2012. Petani padi Sawah dan Kemiskinan. Studi Kasus di Desa Pallantikang, Kecamatan Pattalassang, Kabupaten Gowa) . Jurnal Agrisistem, Juni 2012, Vol. 8 No. 1 Sekolah Tinggi Penyuluhan Pertanian Gowa, Jl. Malino Km 17 Sungguminasa Kab. Gowa

Todaro, Michael P. 1995. Pembangunan Ekonomi Dunia Ketiga. Erlangga : Makassar.

Todaro, Michel P. 2004. Pembangunan Ekonomi Dunia Ketiga. Jakarta: Erlangga.

Todaro, M. dan S. Smith, 2006. Pembangunan Ekonomi. (Terjemahan: M. Haris). Jakarta : Erlangga.

Umar, Husein. 2004. Metode Riset Ilmu Administrasi. Jakarta: PT.Gramedia Pustaka Utama.

Wijanarko, Vendi. 2013. Analisis Faktor-faktor yang Mempengaruhi Kemiskinan di Kecamatan Jelbuk Kabupaten Jember. Skripsi. Jurusan Ilmu Ekonomi Studi Pembangunan Fakultas Ekonomi Universitas Jember.

Waluyo, A. 2011. Mensejahterakan Petani.[Diakses 30 April 2011 pada situs http://www.wikipedia.org/php].

Widhiarso. Teori dan Praktek Pemodelan Persamaan Struktural. Widhiarso.staff.ugm.ac.id/files/widhiarso_teori_dan_praktek_pemodelan_persamaan_struk tural_\%28sem\%29.pdf. Diunduh tanggal 19 Mei 2015.

Wijanto, Setyo Hari. 2008. Structural Equation Modeling dengan LISREL 8.8: Konsep dan Tutorial. Yogyakarta: Graha Ilmu.

Sumber garis kemiskinan : https://www.bps.go.id/Subjek/view/id/23 